\title{
National Parks in Colombia
}

\section{Don Hunsaker II}

Colombia has one of the largest bird faunas in the world - over 1550 species, over 300 mammals, including the endangered spectacled bear and mountain tapir, 350 reptiles and over 1000 fish, and a vast range of habitats, from the tropical rain forest of the Pacific coast and lowland swamps to the spectacular peaks of the high Andes, 20,000 feet and more. In recent years Colombia has set aside over $3 \frac{1 / 2}{2}$ million acres for national parks and reserves, which are described here by Dr Hunsaker, Conservation Co-ordinator with INDERENA (the Government department concerned) for the Peace-Corps-Smithsonian Program in Bogota. Colombia's conservation efforts began in 1919 with the passing of the first laws protecting the fauna and flora. In 1941 the Government introduced hunting regulations, and in 1948 the first biological reserve, La Macarena, was set aside. A law passed in 1954 made the condor the first fully protected species. Since then government, universities and interested people have worked to coordinate, in so far as possible, the national park system, the wildlife service and university projects to protect wilderness and wildlife in this extremely critical region of South America.

Colombia has long served as a faunal and floral corridor for species that have originated in either North or South America and have expanded their populations into the other subcontinent. The country is divided into a series of north-south valleys and parallel mountain chains, the Andes, with the remarkably wet Choco in the north-west and the lowland Amazon basin in the south-east. The isolated valleys with their divergent habitats have resulted in a great variety of plant and animal species. Colombia has one of the world's richest vertebrate faunas, with over 1550 species of birds, 200 amphibians, 350 reptiles, 1000 freshwater fish and over 300 mammals.

The protection and management of the national parks, wildlife and other natural resources is vested in the Instituto de Desarrollo de los Recursos Naturales Renovables (INDERENA), formed in 1969 from then existing governmental agencies within the jurisdiction of the Ministry of Agriculture. The Division of National Parks and Wild life is one of six major offices within INDERENA. The basic philosophy is to use the national parks and reserves to preserve wildlife species and habitat, as well as natural areas for public recreation, at a relatively early stage of Colombia's population and economic development. Some national parks are also being developed for public recreation, especially on the Caribbean coast, where development pressures are exceedingly strong. At the present, INDERENA officials are working on a master plan for the coastal area that will keep as much land as possible in a pristine state but yet permit a significant build-up of tourist facilities outside the parks.

So far over $1,476,888$ hectares $(3,647,904$ acres $)$ of land have been set aside for national parks and wildlife protection thanks to the efforts 


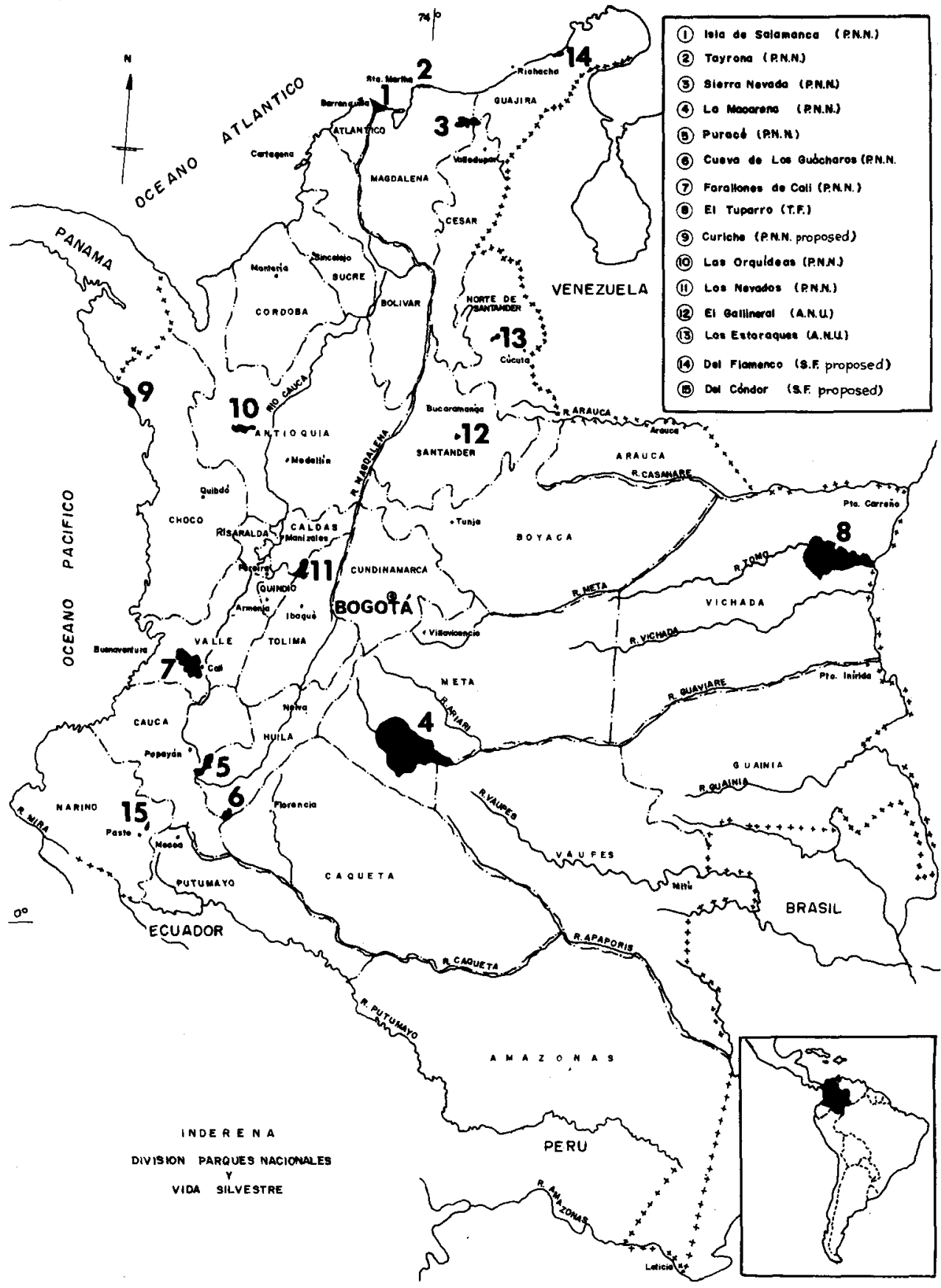

NATIONAL PARKS AND RESERVED AREAS IN COLOMBIA. The numbers correspond with those on the list opposite 


\section{National Parks and Reserved Areas}

1. Isla de Salamanca NP

2. Tayrona National Park

3. Sierra Nevada NP

4. La Macarena NP

5. Purace NP

6. Cueva de Los Guacharos Acevedo; Huila NP

7. Los Farallones NP

8. El Tuparro Faunistic Territory
Sitio Nuevo; Magdalena *

Santa Marta; Magdalena

Santa Marta; Magdalena

Vista Hermosa; Meta

Purace; Cauca

Cali and Jamundi; Valle

Puerto Carreno; Commissary of Vichada

21,000 ha.; 47,870 acres

15,000 ha.; 37,050 acres

50,000 ha.; 123,500 acres

600,000 ha.; $1,482,000$

acres

80,000 ha.; 187,600 acres

700 ha.; 1729 acres $\dagger$

150,000 ha.; 370,500 acres

380,000 ha.; 928,600 acres

Areas to be reserved in 1972 :

10. Las Orquideas NP

11. Los Nevados NP
Urrao, Fron tino and Abriaqui; Department of Antioquia

Manizales and Chichina; 50,000 ha.; 123,500 acres

Pereira and Santa Rosa de Cabal; Salen to and Armenia; Murillo, Casabianca and Villa Hermosa; Departments of Caldas, Risaralda, Quindio and Tolima, respectively

San Gil; Santander

60 ha.; 148 acres

120 ha.; 336 acres

La Playa; Norte de

60,000 ha.; 1482,00 acres

13. Los Estoraques Unique Natural Area

Santander

14. El Flamenco Fauna Sanctuary

15. El Condor Fauna Department of Guajira

Pasto; Narino Sanctuary

*In each case the first name is that of the municipality, the second that of the department.

$\uparrow$ possible expansion of 15,000 ha. is under study.

of a very active group of conservationists, including Dr Simon Franky, head of INDERENA's Park and Wildlife Division, Dr Carlos Lehmann, head of the Department (State) of Valle's Natural History Museum, Dr Jorge Hernandez, head of Wildlife Investigation in INDERENA, Dr Jose Borrero of the University of Valle, and many others. As in all developing countries with rapidly expanding economies and populations, the greatest problems for conservation are the destruction of habitat by settlers and commercial (or personal) use of endangered species for economic gain or food.

The lands set aside for national parks, floral and faunal reserves and biological research, include some of the most beautiful and ecologically important areas of Colombia. All the major ecological associations and life zones are represented from the lowland deserts and seashores to the high paramo and snow-capped peaks. 

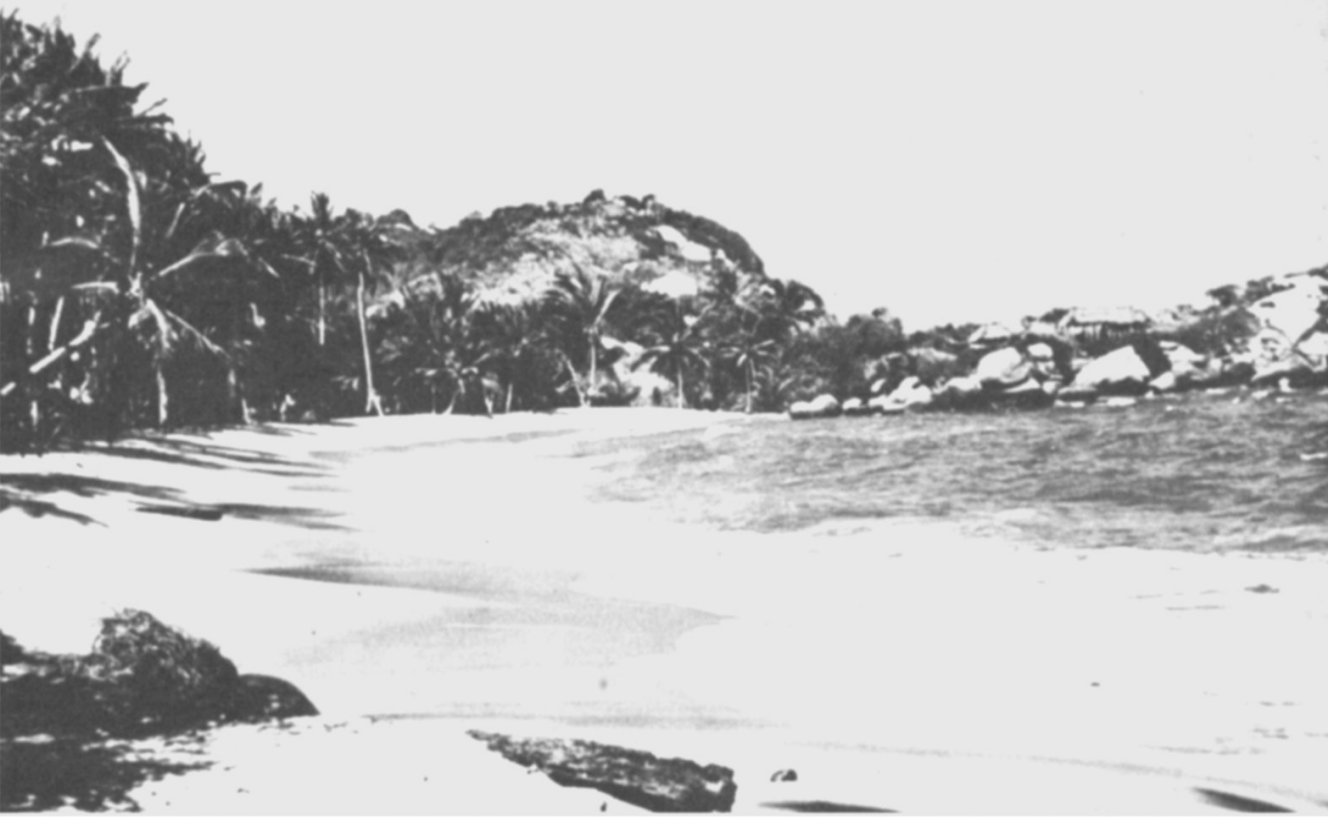

IN THE TAYRONA NATIONAL PARK Richard Fitter

Tayrona National Park on the Caribbean coast, has miles of beautiful beaches on an indented coastline, with a fringing coral reef that provides a habitat for tropical fish, beautiful scenery and excellent swimming. Part of the Sierra Nevada de Santa Marta, an isolated mountain range which rises to over $6500 \mathrm{~m}$., is included. Named after an ancient Indian civilisation, the Tayronas, the park also has a partially restored Indian village, El Pueblito. The vegetation and fauna are exceptionally varied. The dry tropical forests of the lowlands include Hematoxylom, Pereskia and Astromium. The more humid forest ranges up through very wet areas into montane forests. Leathery, loggerhead and green turtles, Eretmochelys imbricata, Caretta caretta, and Chelonia mydas nest on the beaches; Cebus monkeys can be seen without much difficulty, and puma Felis concolor, fox Dusicyon thous, and ocelot Felis pardalis are common. A small population of condors Vultur gryphus inhabits the nearby Sierra Nevada highlands. The park has an access road, headquarters and well-developed camping areas.

Salamanca National Park consists of a long, narrow strip of sandy beach and mangrove swamps separating the great inland lagoon, Cienaga Grande, from the Caribbean. The abundance of waterfowl is spectacular. Herons, egrets, limpkins, ducks, migratory birds and hawks are common, and one large egret rookery with eight species can be watched and studied. Land animals include deer Odocoileus virginianus, capybara Hydrochoerus and raccoons Procyon cancrivorus. Caiman sclerops has been reintroduced, because numbers were depleted due to hunting, and is doing well. Manatees Trichechus manatus are rare but appear to be stable. The park has a visitors' centre, museum and a variety of captive animals displayed in moated areas.

Purace National Park in the south comprises eight volcanic craters on 


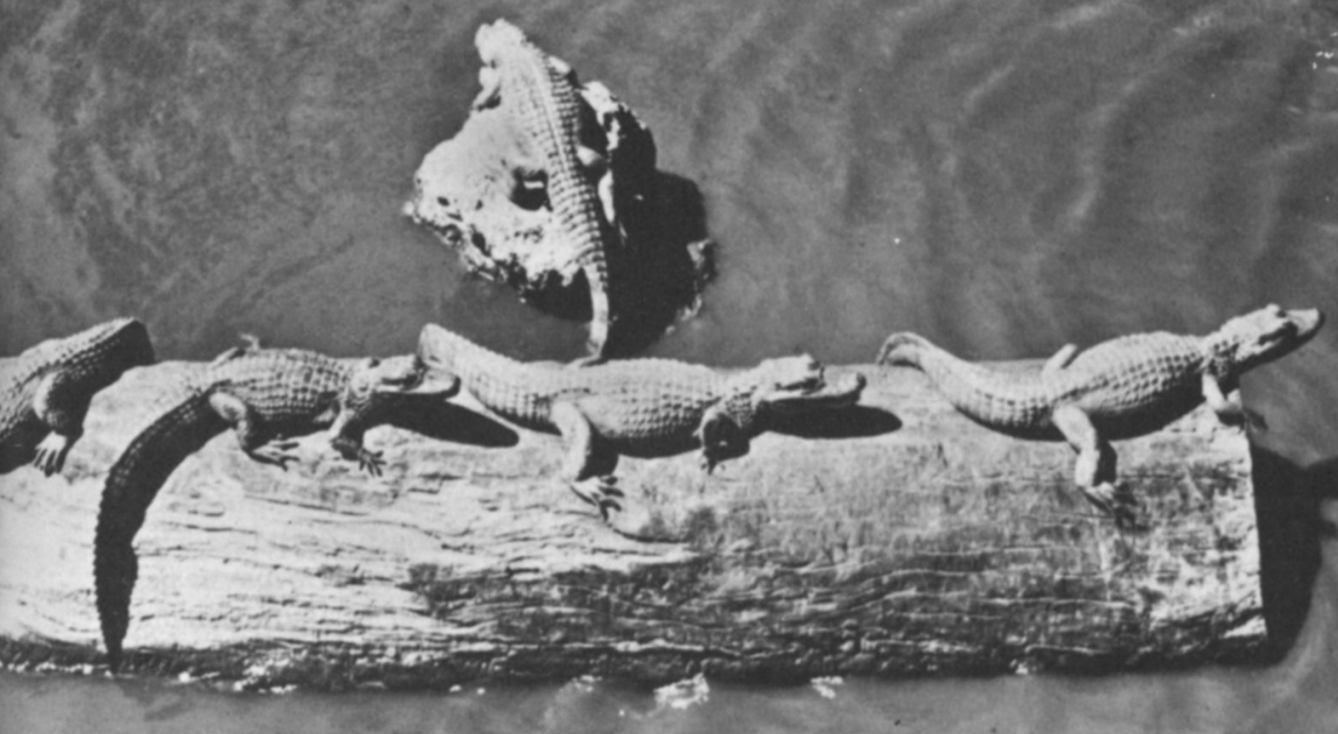

CAIMANS in the moat at the visitor centre in Salamanca National Park Richard Fitter

two large volcanos. Abundant water from snow-covered Volcan Purace, 4760 metres, which last erupted in 1954 , makes this an aquatic paradise. Four of Colombia's major rivers have their headwaters here: the Magdalena, Cauca, Caqueta and Patia, and two endangered species, the South American (spectacled) bear Tremarctos ornatus and the mountain tapir Tapirus pinchaque, are well protected. INDERENA and the Peace Corps Conservation Program are currently monitoring the populations of tapir and bear and the avifauna, which includes over 200 species, among them condors, quetzals, torrent ducks and cock-of-the-rock. High up is the paramo, almost constantly covered with clouds and mist, a wet grassland with bromeliads and sphagnum moss, where the most characteristic plant is the frailejon Espeletia. One area has several geysers and hot water pools. A visitors' centre, warm water swimming pools, picnic and camping sites, and overnight facilities are available.

Los Nevados National Park includes the most spectacular peaks in central Colombia. (All permanent snow-capped mountains have been declared public domain). A road leads up to the snow line on Mt Ruiz, where a small refuge with hot food and drinks is open the year round. The climb to the crater is up a gentle slope, but at $6000 \mathrm{~m}$. it is strenuous. The approaches to the mountain pass through forest of Quercotum and Clethra and up through the paramo zone to barren, stark cinder areas almost devoid of plant and wildlife. In some areas, the snow is tinted red from the algae. The lower areas will be developed for camping and hiking.

La Macarena National Park - This isolated mountain rising abruptly out of Colombia's eastern plain has become the refuge for a great variety of fauna, including species from the Andes, the plains and the jungles of the Orinoco and Amazon. Over 450 species of birds can be found in the jungle which covers 90 per cent of the park area, including 
toucans Ramphastos, cock-of-the-rock Rupicola, many raptors and the harpy eagle Harpia harpya. Over thirty species of orchids include Bifrenaria, Epidendrum and Eulophia and some endemic species, and carnivorous plants are common. The rich primate fauna includes howler Alouatta seniculus, squirrel Saimiri sciureus, spider Ateles belzebuth and cebus Cebus apella monkeys. Jaguar Panthera onca, tapir Tapirus terrestris, and peccary Tayassu tajaco are common. Riverine fauna includes the giant otter Pteroniura brasiliensis, capybara Hydrochoerus, dolphins Inia geoffrensis and the crocodilians Caiman sclerops and Crocodylus intermedius. Many scientific investigations have been carried out in the region.

Cueva de los Guacharos National Park, in the south, features several beautiful and interesting caves where oil birds Steatornis caripensis nest, and the only area for Colombia's largest species of tinamou, Tinamus osgoodi. A road leads to the largest of the caves, which are in a forest of pines, cedar, walnut and palm, with an abundance of orchids.

Sierra Nevada National Park encompasses the heights of the Sierra Nevada de Santa Marta, an isolated mountain range rising from sea-level to almost 19,000 feet in only 27 miles, and includes Colombia's highest peak, Simon Bolivar. From the dry deserts of the east, it rises through all the life zones to the paramo, with the vegetation and animal life typical to each zone. There are no tourist facilities, but these are now in the planning stage.

El Tuparro Faunistic Territory, comprising part of the vast grasslands of eastern Colombia, interlaced with gallery forests up to $50 \mathrm{~m}$. high, protects among others the giant otter Pteronura which is relatively common, the giant armadillo Priodontes (over four feet long), and the Orinoco crocodile Crocodylus intermedius. The primary grass species is Trachypogon vestitus, with the shrubs Brysonima and Palicourea common. Bird species include guans Penelope, curassows Mitu, thickknees Burhinus bistriatus, the fork-tailed flycatcher Muscivorus tyrannus, tinamou and many raptors. Common reptile species are turtles, Podnocnemis expansa, $P$. unifilis and P. vogli; boas Boa constrictor; anacondas Eunectes murinus; and iguanas Iguana iguana. The area is an excellent one for research on almost any of the lowland species of wildlife. The name is derived from the Tuparro River which forms the southern boundary.

Los Farallones National Park, in central Colombia, near Cali, includes a series of deep river valleys which cut through the bed rock to form large cliffs, the 'farallones'. It ranges from $200 \mathrm{~m}$. in the rain forest on the Pacific side to $4260 \mathrm{~m}$. in the Pico de Parice, with virgin forests and great rivers, and a fauna that includes mountain tapir and spectacled bear. As yet there is no visitor development.

Considerable effort has been expended to protect Colombia's flora and fauna, but law enforcement is very difficult. Some species have full protection, and others protection from hunting in their breeding seasons, but most rural people are avid hunters and eat almost any animal they can capture. INDERENA is now building up its enforcement $\mid$ branch. 
Mammals

Mountain tapir

Giant armadillo

Pudu deer

Pacarana

Giant otter

River otter

Manatee

Amazon manatee

Cotton-top marmoset

South American (spectacled) bear

Birds

Cock of the rock

Trogons

White-tailed

Violaceous

Black-throated

Blue-crowned

Blue-tailed

Slaty-tailed

Collared

Black-tailed

Highland

White-tipped quetzal

Quetzal

Pavonine quetzal

Golden-headed quetzal

Vermilion cardinal

King vulture

Condor

Mockingbird

White ibis

Red ibis

Jabiru stork

Roseate Spoonbill

Black-necked grebe

Yellow-billed pintail

Cinnamon teal

Flamingo

Blackbird

Oil bird

\section{Reptiles}

Amazonian turtle

Smooth-fronted caiman

Dwarf caiman

Orinoco crocodile

Black caiman
Tapirus pinchaque

Priodontes maximus

Pudu mephistophiles

Dinomys branickii

Pteronura brasiliensis

Lutra enudris

Trichechus manatus

Trichechus innunguis

Leontocebus oedipus

Tremarctos ornatus

Rupicola rupicola

$R$. peruviana

Trogon viridis

$T$. violaceus

T. rufus

T. curucui

T. comptus

T. massena

T. collaris

$T$. melanurus

$T$. temperatus

Pharomachrus fulgidus

$P$. mocinno

$P$. pavoninus

$P$. auriceps

Cardinalis phoeniceus

Sarcoramphus papa

Vultur gryphus

Mimus polyglottos (gilvis)

Eudocimus albus

E. ruber

Jabiru mycteria

Ajaia ajaja

Podiceps nigricollis

Anas georgica

A. cyanoptera

Phoenicipterus ruber

Icterus icterus

Steatornis caripensis

Podocnemis expansa

Paleosuchus trigonatus

$P$. palebrosus

Crocodylus intermedius

Melanosuchus niger. 


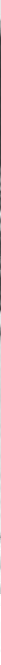

IN THE SALAMANCA NATIONAL PARK, home of innumerable water birds Richard Fitter

In general, Colombia is undergoing an awakening to its beauty and the need to conserve its disappearing resources. Concern over pollution, tourism and habitat destruction is being voiced at least in the large cities and some governmental agencies. Hopefully the trend will continue and future generations will be able to enjoy the beauty and abundance of flora and fauna that now exists.

\section{DEFINITIONS IN COLOMBIA}

National Natural Park: an area ecologically auto-regulated that is reserved, delineated and declared by INDERENA for its natural values representative of the fauna, flora, and national scenic beauties of a region, with the purpose of conserving them in perpetuity, subjecting them to special rules of management so that in being used by the public for recreation they do not suffer significant alternations.

Unique National Area: an area delineated, reserved and declared as such by INDERENA for possessing special conditions of flora and earth formations which make up a natural scenery of rare frequency.

Faunistic Territory: an area reserved, delineated and declared as such by INDERENA for the investigation, study, conservation, propagation, management and utilisation of the wildlife, with demonstrative purposes.

Flora Sanctuary: an area reserved and delineated by INDERENA for the preservation of a vegetable species or community; all other interest and activities are subordinated to this end.

Fauna Sanctuary: an area reserved and delineated by INDERENA for the preservation of an animal species or community, where all other interests and activities are subordinated to this end. 